\title{
Journalistic Metadiscourse: Access to the Media's Public Sphere
}

In a democratic society, it is expected that all sections of society have access to the press because it serves as a major medium of information and communication. If individuals are to contribute to policymaking through participating in public debates, then all sections of society will need to have access to the press, especially when issues that concern them are the subjects of debate; this has not been the case. The press has often been accused of giving more access to elite and official sources to the detriment of the less powerful in society (Galtung and Ruge 1965, cited in Harcup and O'Neill 2010, p. 270). Reference to "elite" sources here is not so much the politically powerful, as may have been the concept of Galtung and Ruge but is what Harcup and O'Neill referred to as "the power elite". The power elite could be celebrities, policymakers and the press, amongst others.

The danger of favouring the debates of the "power elite" is that the views of a stratum of society dominate the media discourse while those of the less powerful are hardly heard. The "power elite" can become the primary definer of the debate (Hall et al. 1978. pp. 57-59, cited in Allan 2010 , p. 84). The primary definers define the trend of the debate because they often come high up in the news narrative and as such the rest of the debate may be a response to their argument or to their definition of the subject. Relating this to media reform, ideas and interpretations for press reform may be limited to those mentioned or advocated by the primary definers. This can result in the media transmitting a narrow spectrum of ideas on media reform. Their proposals or arguments on media reform

B. Ogbebor, British Media Coverage of the Press Reform Debate, https://doi.org/10.1007/978-3-030-37265-1_9 
may also get more reads if readers stop at the first few paragraphs of a report on media policy. In the journalistic metadiscourse on the press reform debate that followed the NoTW that followed the phone hacking scandal, the press emerged as a major power elite. This chapter shows how the press took advantage of its powers to control information to give more quality access to arguments that it perceived to be in its interest, to the detriment of other stakeholders in the press reform debate.

To a lesser degree, policymakers, victims of press abuse and their campaigners also emerged as key sources used in the journalistic metadiscourse on the press reform debate. In this book, a source refers to "any person, institution, or document to which the reporter explicitly attributed information" (Hallin et al. 1993, p. 754). Table 9.1 reveals that 46.1 per cent of news sources on the debate were press related; out of this number, 37.3 per cent were journalists (not editors), 3.7 per cent were news editors; 2.8 per cent were from press bodies such as the PCC and IPSO, while 2.3 per

Table 9.1 Frequency of sources

\begin{tabular}{lrc}
\hline Sources & Frequency of sources & Percentage of sources \\
\hline Campaigners for victims of press abuse & 537 & 4.5 \\
Leveson Inquiry & 827 & 7.0 \\
Royal Charter & 97 & 0.8 \\
Campaigners for press freedom & 495 & 4.2 \\
The press & 4420 & 37.3 \\
Press body such as IPSO & 331 & 2.8 \\
News editors & 441 & 3.7 \\
Newspaper and magazine publishers & 278 & 2.3 \\
Conservative spokesperson & 776 & 6.5 \\
Police & 253 & 2.1 \\
Labour shadow government & 573 & 4.8 \\
Coalition Liberal Democrats & 325 & 2.7 \\
Cross-party & 85 & 0.7 \\
Culture, media and sport & 255 & 2.2 \\
Government spokesperson & 453 & 3.8 \\
Other politicians & 454 & 3.8 \\
Victims of press abuse & 559 & 4.7 \\
Ordinary members of the public & 184 & 1.6 \\
Judiciary & 263 & 2.2 \\
Other & 252 & 2.1 \\
Total & 11,858 & 100.0 \\
\hline
\end{tabular}


cent came from newspaper and magazine publishers (see Tables 9.1 and 9.2 ), demonstrating a clear inequality in the distribution of sources used by the press in its coverage of the debate.

This inequality in the distribution of sources was also identified in the category of writers of articles in the study sample. Understandably, newspaper staff wrote the bulk of the stories on the coverage, accounting for 91.5 per cent of writers of articles on the debate (see Tables 9.3 and 9.4). What is of interest is the distribution of other contributors (writers) from outside the newspaper's staff. Out of the remaining 8.5 per cent of contributors (outside the newspaper's staff), 4.3 per cent were press related: 2.2 per cent were from "other media" organisations, 1.4 per cent were written by campaigners for press freedom and 0.7 per cent were from former media executives (see Table 9.4). The remaining 4.1 per cent were shared among eight other contributors. This result does not reflect a democratic public sphere. It agrees with arguments by previous studies that the media is dominated by a narrow spectrum of sources (Graber and Dunaway 2014). The dominance of the media as sources within an already narrow spectrum of sources is a double cause for concern. The gap between press-related sources and other sources in the discourse (see Table 9.2) demonstrates how the gatekeeping power of the press can be used to their advantage (Lewin 1947, 1951, cited in Shoemaker and Vos 2009 , p. 1).

Kurt Lewin $(1947,1951)$ used the theory of gatekeeping to show "how food made its way from the grocery store or garden to the dinner table" (cited in Shoemaker and Vos 2009, p. 109). White (1950, cited in Shoemaker and Vos 2009, p. 112) extended the gatekeeping concept to

Table 9.2 Source types in related categories

\begin{tabular}{lc}
\hline Source type & Percentages \\
\hline Press-related sources & 46.1 \\
Policymakers & 24.5 \\
Press abuse victims-related sources & 9.2 \\
Leveson and Royal Charter & 7.8 \\
Judiciary & 2.2 \\
Police & 2.1 \\
Ordinary members of the public & 1.6 \\
Other & 2.1 \\
Total & 100.0 \\
\hline
\end{tabular}


Table 9.3 Category of writers

\begin{tabular}{|c|c|c|c|c|c|c|c|}
\hline Category of writers & $\begin{array}{l}\text { Guardian } \\
(\%)\end{array}$ & $\begin{array}{l}\text { Daily } \\
\text { Mail } \\
(\%)\end{array}$ & $\begin{array}{l}\text { Daily } \\
\text { Mirror } \\
(\%)\end{array}$ & $\begin{array}{l}\text { Daily } \\
\text { Telegraph } \\
\text { (\%) }\end{array}$ & $\begin{array}{c}\text { Daily } \\
\text { Express } \\
(\%)\end{array}$ & $\begin{array}{l}\text { The } \\
\text { Sun } \\
(\%)\end{array}$ & $\begin{array}{c}\text { Total } \\
(\%)\end{array}$ \\
\hline $\begin{array}{l}\text { The newspaper's } \\
\text { staff/ } \\
\text { representative }\end{array}$ & 88.2 & 98.3 & 94.1 & 91.5 & 92.9 & 88.5 & 91.5 \\
\hline $\begin{array}{l}\text { Campaigners for } \\
\text { victims of the } \\
\text { press }\end{array}$ & 0.9 & & & 1.0 & & 1.0 & 0.7 \\
\hline $\begin{array}{l}\text { Victims of press } \\
\text { abuse }\end{array}$ & 0.9 & & & & & & 0.3 \\
\hline $\begin{array}{l}\text { Campaigners for } \\
\text { the press }\end{array}$ & 1.2 & 1.2 & 2.0 & 0.5 & & 4.2 & 1.4 \\
\hline $\begin{array}{l}\text { Representatives of } \\
\text { associations }\end{array}$ & 0.9 & & & & & & 0.3 \\
\hline $\begin{array}{l}\text { Former media } \\
\text { executives }\end{array}$ & 0.6 & & & 0.5 & 7.1 & 1.0 & 0.7 \\
\hline $\begin{array}{l}\text { A member of the } \\
\text { public }\end{array}$ & & & 2.0 & 1.0 & & & 0.3 \\
\hline Government & & & & 1.5 & & & 0.3 \\
\hline Politicians & 1.2 & & & 2.5 & & 1.0 & 1.1 \\
\hline $\begin{array}{l}\text { Business/ } \\
\text { corporate } \\
\text { organisations }\end{array}$ & & 0.6 & & & & & 0.1 \\
\hline Academics & 1.5 & & 2.0 & 0.5 & & 1.0 & 0.9 \\
\hline Other media & 4.3 & & & 1.0 & & 3.1 & 2.2 \\
\hline Total & 100.0 & 100.0 & 100.0 & 100.0 & 100.0 & 100.0 & 100.0 \\
\hline
\end{tabular}

Table 9.4 Category of writers in groups

\begin{tabular}{lr}
\hline Writers & Per cent \\
\hline Newspaper staff & 91.5 \\
Press-related sources & 4.3 \\
Policymakers & 1.4 \\
Press abuse victims-related sources & 1.0 \\
Academics & 0.9 \\
Representative of associations & 0.3 \\
Corporate organisations & 0.1 \\
Ordinary members of the public & 0.3 \\
Total & 100.0
\end{tabular}


mass communication research. Applying this theory to news, Shoemaker and Vos $(2009$, p. 1) pointed out that the enormity of information available to the media and the limited amount of space to transmit it necessitated the need for the press to filter information in order to transmit a manageable quantity to the public. The process by which the media decide which stories among the lot to tell, which not to tell, who speaks about them (sources) and what versions of interpretation to relay to the public is what is referred to as gatekeeping (Shoemaker and Vos 2009; White 1950, cited in Vos and Heinderyckx 2015, p. 3).

In the words of Shoemaker and Vos $(2009$, p. 1), gatekeeping "is the process of culling and crafting countless bits of information into the limited number of messages that reach people each day" (Shoemaker and Vos 2009 , p. 1). This process of selection can be based on cultural, economic and ideological factors. Examples of such factors include a newspaper's political ideology, its ethos, ownership and business interests. This endows the media with enormous powers because they have the power to decide whether to allow some arguments or sources into the news or whether to give them limited access or to keep them out completely (Rozell and Mayer 2008, p. 328). This gatekeeping power, if not checked, can be used in a way that gives the press undue advantage in their transmission of debates, especially debates about themselves (Van Heerden 1996, cited in Fourie 2001, p. 205). Shoemaker and Vos (2009, p. 122) affirmed that gatekeeping can be used in the selection of sources.

The gatekeeping theory is closely linked to agenda-setting (McCombs et al. 1997; McCombs 2004, 2014). Agenda-setting "is the process of the mass media presenting certain issues frequently and prominently with the result that large segments of the public come to perceive those issues as more important than others" (Wahl-Jorgensen and Hanitzsch 2009, p. 147). Agenda-setting studies have shown that media messages, depending on a number of political and social factors, can influence an individual's action as well as determine his or her depth of knowledge on the issues represented (Negrine 1989, pp. 3-4). Agenda-setting studies have "established that journalists and editors have great power both to shape the main topics of importance to audiences as well as the details of those issues" (Wahl-Jorgensen and Hanitzsch 2009, p. 154). My intention is not to argue for or against media effects but to highlight the fact that how the media cover debates about their policy is important because it could (depending on other social and political factors) shape the public's perception and consequent action about media reform. The results of my research 
confirms that in the coverage of the media reform debate, the press used their gatekeeping powers to see to it that their voices dominated the debate, particularly regarding arguments on how the press should be regulated.

In their use of press-related sources, a trend emerged which I would like to flag up for further investigation. It is a trend in which newspapers reported the publications or transmissions of other media organisations about the debate: a situation that can be described as "media coverage of media coverage of media issues"-a kind of second-level metacoverage. This manner of coverage was done by the two sub-interpretive spheres, each using it to strengthen their own argument while countering opposing views in the press reform debate. Headlines such as "Times editor says papers will go ahead with own regulator" in the Guardian newspaper (O'Carroll and Halliday 2013, p. 16); 'The Economist call press regulation deal 'a shameful hash' " in the Guardian newspaper (Greenslade 2013b); "Now the Economist rejects rotten plan to shackle free press" in Daily Mail (Chapman 2013, n.p.) and "The Spectator says NO to the press regulator" in the Guardian newspaper (Greenslade 2013a, n.p.) are some examples of this second-level metacoverage. This pattern of coverage featured more in Guardian than in other newspapers in the study sample.

Guardian newspaper used this second-level metacoverage both to commend papers that were of a similar view to its position in the debate and to condemn those newspapers that were of a different view. For example, in an article headlined "Editors speak out on regulation" Neild (2013, p. 8) in his report for the paper analysed the editorial sections of Financial Times, Independent and itself-Guardian, celebrating their views on statutory underpinning of the new press regulator and pointing out that all three [at the time] did not consider statutory underpinning as a threat to press freedom:

An editorial in today's FT said the failure to agree on a regulatory regime would threaten vital economic reforms and could result in a backlash. "What is now needed is a practical gesture of goodwill to break the deadlock and avoid a sweeping press law" it said. The Guardian, in its editorial, ... warned that by refusing to give ground on regulation, editors were gambling with the freedoms they sought to protect. The Independent said that the arguments against some form of statutory underpinning had lost perspective. "Even reasonable half-way measures are characterised as press freedoms eroded and democratic principles laid waste," it said. (Neild 2013, p. 8) 
In a similar article, it wrote, "Finally, medals to the Financial Times, the Independent and the Guardian for holding out against ferocious peer pressure from the rest". Meanwhile, in another article headlined "Will the press repent its nasty ways?" Guardian used this second-level metacoverage to condemn other media for arguing that statutory underpinning amounted to a threat to press freedom. The papers were used as sources in order to ridicule them and portray their arguments as lacking substance, as can be seen in this excerpt from Guardian:

I loved the heroics of Spectator editor Fraser Nelson, saying he'd never pay any fine from an "underpinned regulator": "Whether I'd go to prison or not is up to the enemies of press freedom to decide. At least it would make clear what they are proposing." ...Oh, the lofty rhetoric of the Sun, quoting from those they would have hounded at the time-JF Kennedy, Ralph Miliband, Adlai Stevenson, John Stuart Mill and Gandhi. But it has been sad to see some of the wiser commentators on the Times and Telegraph follow their masters' voice, warning that the end is nigh when they must know quite well that's nonsense. (Toynbee 2013, p. 29)

Similarly, Daily Mirror and Daily Telegraph reported the comments of other media organisations, using the method to either advance or counter arguments. An example is an article from Daily Mirror which attributed the closure of the News of the World to inaccurate reporting on the part of Guardian:

Roll forward five months and a much smaller story appeared on the front of The Guardian. The headline- "New inquiry into Dowler hacking launched"- gave little clue as to the revelation in the story, namely that the deletion exposé was wrong. The single-most stomach-churning element of the whole saga was, in fact, incorrect. It seems the messages had most likely been deleted automatically and not by journalists "thirsty for more" as the initial Guardian report claimed. (Embley 2012, pp. 8-9)

There were also headlines such as "Politicians in control risks media like Russia's, warns Lebedev" (Ross 2012, p. 8). Evgeny Lebedev, the owner of the London Evening Standard and Independent newspaper (solely online at the time of this study), was speaking on The Andrew Marr Show on $\mathrm{BBCl}$. This dominance of the opinions of the press in the journalistic metadiscourse on the debate affirms that the media does not serve as a democratic public sphere during debates about their policy. Both spheres 
of journalistic metadiscourse took advantage of their gatekeeping powers to allocate disproportionate amounts of space to their voices in the press reform debate. As stated earlier, about half of the total number of sources used in the coverage were press related.

The press became the major power elite with the dominant voice while the rest of society were, apparently, at its mercy in the debate. Though it can be argued that there are various channels through which the public can participate in this debate, such as from online news websites and blogs that advance counter discourses, it has been established through previous research that considerable numbers of people still depend on the mainstream press for hard news content (Haas 2012, p. 148). Despite the dive in newspaper readership in the UK (Newsworks 2016; Department for Digital, Culture, Media and Sport 2019), the national press examined in this study, at the time of writing, still had an average daily readership of 12.2 million which demonstrates the number of people in society consuming discourse from this doubly narrow spectrum of sources. Interestingly, the views of the press were not only expressed by press-related sources but were also passed across through other sources such as policymakers. In this book, policymakers refer to the government, government institutions and politicians.

Out of the remaining 53.9 per cent of sources (apart from the press' 46.1 per cent), policymakers made up 24.5 per cent of sources: 6.5 per cent of the number were Conservative Party spokespersons, 4.8 per cent were from the Labour Party, 3.8 per cent were Government spokespersons, another 3.8 were "other politicians", 2.7 per cent were from the Liberal Democratic Party who were then in coalition government with the Conservatives; 2.2 per cent of sources were from the Department of Culture, Media and Sports (DCMS); and 0.7 were cross-party-a team made up of the three major political parties-Conservatives, Liberal Democrats and Labour (see Tables 9.1 and 9.2). Similarly, policymakers made up a significant proportion of contributors outside of journalists (see Tables 9.3 and 9.4), making them another significant group used as sources.

Policymakers play a vital role in media policy debates, in the sense that they are the decision-making sphere; they are the forum where contestations in the media's public sphere can progress to the stage of a consensus and the stage where the debate can influence political action. In this case, the political action to be taken is a decision on how to ensure an accountable press but as Putnis (2000, p. 105) observed, "the interdependence of 
politics and the media renders media policy making a particularly fraught and contentious process". That is because the media and policymakers depend on each other for a number of purposes. O'Heffernan (1991, p. 38) divided policymakers' use of the media into four categories. $\mathrm{He}$ noted that policymakers use the media "for immediate useful information"; "in the early stages of an issue to make a decision"; as "the only source of policy information" in times of crisis and as "critical information for policy making" (ibid.). It is important to note that policymakers' uses of the media go beyond the making of policy to other more personal reasons, such as the promotion of their political image or popularity (Silverstone 2007, cited in Sanders 2008, p. 38).

As Putnis (2000, p. 105) pointed out, policymakers are not uninvolved parties in media policy creation or reform because "they crave media support; and their political fortunes are influenced by media reporting". Their power to make policy decisions also makes the media dependent on policymakers for what they consider to be favourable media policies. Collusion or mutual support between politicians and the media has the potential to shape media content and affect media policy reform. Politicians are known to have entered mutual agreements with media proprietors to give favourable coverage to their political party in exchange for media policies that favour the proprietors' corporate interests. For instance, the Labour Party's Tony Blair was said to have made an agreement with Rupert Murdoch before the 1997 general election in the UK, whereby his papers' support for the Labour Party was earned as a reward for cross-media ownership rules that favoured the media mogul (Franklin 2002, p. 30). Franklin described the period as one "characterised by an extraordinary degree of non-decision making in media policy" (ibid.).

Similarly, former Conservative Prime Minister David Cameron's close relationship with Rupert Murdoch was also suggested as one of the reasons for his election successes (Mason and Martinson 2016). Within 18 months, from April 2015 to September 2016, "News Corp executives had 20 meetings with senior government representatives" in Downing Street (Mason and Martinson 2016, n.p.; Media Reform Coalition 2017). Shortly after taking up office as Prime Minister, Theresa May visited the media magnate Rupert Murdoch in New York, when she visited for a United Nations meeting (Mason and Martinson 2016), affirming the cosy relationship between policymakers and the media. This reciprocal relationship is arguably the reason why Rupert Murdoch who lost his initial bid for the remaining shares of BskyB (he owned 39 per cent at the time) in 
the heat of the phone hacking scandal was able to relaunch his bid for Sky in 2016, through his 21 st Century Fox company (Guardian 2016; BBC News 2017). Note that in 2014, BskyB (a merger of British Satellite Broadcasting and Sky Television) further merged with Murdoch's PayTelevision companies in Germany (Sky Deutschland) and Italy (Sky Italia) to form Sky (Reuters 2018).

Rupert Murdoch's relaunch of the Sky bid shows that the phone hacking scandal was not enough to put the owner of the defunct News of the World on the government's blacklist. As part of rebranding after the News of the World phone hacking scandal, Rupert Murdoch divided his media empire into 21st Century Fox, comprising of his cable network programming, filmed entertainment, television, direct broadcast and satellite TV (21st Century Fox 2017); and News Corporation comprising of his print media (News Corporation 2017). 21st Century Fox was vying for an $£ 11.7$ billion takeover of the broadcast company (Dean 2017). The deal was cleared by the European Commission competition authorities but following a petition posted on the campaigning website 38 Degrees, which gathered over 300,000 signatures (38 Degrees 2017; Sweney 2016, n.p.), the deal was referred to Ofcom, the communications watchdog, for a public interest assessment in relation to media plurality and broadcasting standards (Dean 2017, n.p.). Though Ofcom reported that the deal could give the Murdoch family "increased influence", 21st Century Fox was eventually given the go-ahead to participate in an auction for Sky along with Comcast and Walt Disney (Guardian 2016; King 2016). Though this contest culminated in 21 st Century Fox company's loss of the Sky bid to Comcast in 2018, it can be argued that Rupert Murdoch was allowed to bid for Sky despite the involvement of his defunct News of the World in the phone hacking scandal because of the cosy relationship that existed between him and the government (Financial Times 2018; Waterson 2018).

The relationship between policymakers and the media during periods of media policy debates has also been adversarial. Adversarial in the sense that the press gives indirect warnings to politicians that there would be casualties (political payback) if they go ahead with press reforms, especially where statutory regulations are proposed (Putnis 2000, pp. 105-110; Curran and Seaton 2010; Pickard 2015, pp. 177-189). History has confirmed that there are indeed casualties for persons or institutions that advocate stringent press reforms. For example, David Mellor, when he was National Heritage Minister (now the Department for Culture, Media and Sports), in 1989 warned the press that they were "drinking in the last 
chance saloon"; in other words, the press had one more chance to improve their conduct or be slammed with a privacy law (Keeble 2008, p. 136). He lost his job over a sex scandal revealed by the press in 1992 (Keeble 2008, p. 136; Fletcher 2015). Similarly, Maria Miller, who was Culture Secretary during negotiations for a Royal Charter underpinned by statute, was forced to resign from the role over an expenses scandal reported by the press (BBC News 2014). Though the MPs' expenses scandal first emerged in 2009, the problem with her expenses was brought to the fore by the press in 2014, after she began negotiations to underpin the press regulatory body with a statute. This demonstrates the power of the press to manage information to its own perceived advantage.

Resistance to press reform shapes the way media policy debates are covered and the way they are covered can determine the outcome of media policy. Considering the importance of the media to the sustenance of democracy, steps need to be taken to ensure that media representation of media policy does not jeopardise efforts at effective media reform. In the journalistic metadiscourse on the press reform debate, the press apparently used their gatekeeping powers to ensure that policymakers who expressed support for their position in the debate had more opportunities to function as contributors in their newspapers. For instance, policymakers who were contributors to Daily Telegraph were largely in support of the argument that statutory underpinning was a threat to press freedom (Johnson 2012a, p. 4; Mason 2012, p. 26), while those who were contributors to news articles in Guardian countered the argument that statutory underpinning posed a threat to press freedom (Lester 2012, p. 30; Fowler 2013, p. 24; Huhne 2013, p. 36). And in the articles, some policymakers virtually reproduced the newspaper's position in the debate. For example, Boris Johnson, who was the then Mayor of London (at the time of writing, he had become UK's Prime Minister), wrote an article in The Sun titled "It's one of the glories of this country that we have free, exuberant media. They keep public life much cleaner \& that makes Britain a wonderful place to live" (Johnson 2012b, pp. 10-11). The dominant theme of that report was "against press law and statutory underpinning".

On the other hand, an article written by a member of the House of Lords, Norman Fowler, and published by Guardian newspaper expressed support for statutory underpinning of a new press regulatory body (Fowler 2013 , p. 24). The fact that Norman Fowler, a former Conservative Cabinet minister and party chairman, gained access to publish his view on the debate in the left-wing-leaning Guardian goes a long way to show that 
the primary criteria for access in this metacoverage may have been tied to the position of the newspaper in the debate. It appeared as if the press had said "you either dance to our tune or find somewhere else to publish your view". This trend can, arguably, be described as collusion between politicians and the media.

When it was revealed in 2016 that four newspapers (The Sun, Independent, Mail on Sunday and Independent on Sunday) were privy to information that the then chairman of the Commons Culture, Media and Sport Committee, John Whittingdale, had previously been involved in a relationship with a woman he met on an online dating website who happened to be a sex worker, and had not published it, some media reform campaigners and the Labour Party alleged that some sort of deal may have taken place between this executive and the press (BBC News 2016). John Whittingdale, who was then the Conservative MP for Maldon and East Chelmsford, denied any such deal with the press, and the newspapers claimed they decided not to publish because he was not a minister at the time of the relationship and as such it was not in the public interest (ibid.). Though this sounds reasonable, history has shown that the same "reasonable" position is not applied to all politicians as the unsubstantiated piggate publication by Daily Mail shows. In the piggate story Ashcroft and Oakeshott (2015) claimed that while studying at Oxford University, the then Prime Minister took part in an initiation ceremony at a Piers Gaveston event in which he "inserted a private part of his anatomy into the animal's mouth". The Daily Mail did not reject this story even though David Cameron was not a PM when it allegedly happened. This suggests the special treatment given to John Whittingdale may be a form of collusion.

There were also assumptions that Boris Johnson may have danced to the tune of the bulk of the national press in the press reform debate because he had an ambition to become the next Prime Minister of Britain after David Cameron and would, therefore, need the support of this large section of the national press. It is interesting to note that at the time of writing, Boris Johnson had become the Prime Minister of Britain. Whether or not there was a deal between the press and John Whittingdale or even a personal move by Boris Johnson to seek the press' favour for political ambition, the fact remains that some politicians in both spheres largely reproduced arguments of the press in the debate. It is worthy of note that while the Leveson Inquiry condemned the relationship between the press and politicians for being "too cosy" (Leveson 2012, p. 1969; Winnett 
2012 , p. 11), the very coverage of the inquiry and that of the rest of the debate appear to have been shaped by a similar level of closeness.

The consequence for democracy here is that checks needed to prevent abuse of power by both the fourth and third estates of the realm gradually become eroded (Allan and Zelizer 2010, p. 48). As discussed in Chap. 2, the press in a democratic society is expected to keep political and other powerful institutions in check by exposing corruption, providing information they need to make quality decisions and providing the masses with the relevant information they need to vote in the right political leaders. That is why collusion between the press and politicians poses a threat to democracy. It can, for instance, result in the emergence to power of a politician who though without the quality to lead cosied up to the press or benefited its financial interest in some way. It can also weaken the power of politicians to make policy decisions that can ensure a responsible press.

Another significant group of sources (though to a smaller degree when compared with the press-46.1 per cent, and policymakers-24.5 per cent) in the media coverage of the press reform debate is press abuse victims-related sources. They were used as sources in 9.2 per cent of the coverage: 4.5 per cent were campaigners for victims of press abuse, while 4.7 per cent were the victims themselves. The categorising of campaigners for victims and the victims themselves was a little difficult because some prominent campaigners for victims, like Hugh Grant, were also victims of press abuse. At such times, the context of the story determined the group they fell into. For instance, if Hugh Grant was used as a source with regard to victims, he was recorded as a victim, but if he was cited with regard to victim campaigners, then he was considered a campaigner for victims. The following section analyses the use of sources related to victims of press abuse.

\section{VICTIMS AS “THE STAKEHOLDERS”}

Though the number of press victims-related sources is far less than the number of press and policymakers-related sources (see Tables 9.1 and 9.2 ), the victims of press abuse and their campaigners still emerged as one of the stakeholders whose voices featured in a significant proportion of the debate, accounting for 9.2 per cent of the sources and 1 per cent of the 8.5 per cent of contributors that are not newspaper staff (see Tables 9.1, 9.2, 9.3 and 9.4). While I agree that this demographic is very important to the debate and ought to have been given more space in the journalistic 
metadiscourse, I argue that the construction of victims as "the stakeholders" is further marginalisation of other sections of society.

One major problem with the construction of victims as "the stakeholders" is its composition. A look at the victims used as sources revealed that they were mostly famous (well-known) people. They included persons whose life stories attained the status of newsworthiness because of their celebrity status or high public profile (Harcup and O'Neill's 2010, p. 270). Among them were actor Hugh Grant (Sweney 2013, n.p.), comedian Steve Coogan (O'Carroll 2012, n.p.), singer Charlotte Church (Glover 2012 , n.p.) and author JK Rowling (Luckhurst 2012, p. 25).

Another group of victims used as sources included persons who became famous because of their connection to a newsworthy event such as the Dowlers (Rayner 2012, p. 6), the McCanns (Beattie 2013, p. 26), Christopher Jefferies (Allen and Evans 2012), the 7 July 2005 London bombing survivor (Hill 2012), or persons closely related to any of the two categories of victims (Cohen 2013). So, famous people that have been hurt by the press were constructed as "the stakeholders". That is of course a narrow spectrum of stakeholders of the British press. Though victims of crime such as the Dowlers and the McCanns have been described as ordinary people in some news articles, that is contestable. The debate can thus be classed as an elitist debate. Though it may be argued that the press would more likely invade the privacy of the rich or famous than the ordinary citizen in society, studies show that ordinary citizens are also affected by press excesses: an example is minority groups who are often stereotyped in the news. Such people ought to have been adequately represented in the debate on press standards in the media's public sphere.

People from other sectors of society such as those who have not faced any form of press misconduct should have also formed a relevant demographic as their views may be much more neutral in relation to how to balance the issue of privacy with that of press freedom. My intention here is not to belittle the importance of the victims of press misconduct to the debate but to argue that they are only one relevant demographic out of a number and that should have been reflected in the journalistic metadiscourse. There is the tendency that victims advocating for press reform can make suggestions out of anger and frustration at the press. Therefore, a mix of those that have experienced press abuse and those that have not been directly hurt would have made a more balanced group of stakeholders. What emerged instead was a rhetoric or discourse that constructed the victims of press abuse as the only demographic that needed the service of 
an accountable press. As such, whatever proposal was going to be made by the Leveson Inquiry must pass "the victims test". Policymakers, the press and even the victims themselves all advanced this rhetoric as can be seen in this statement written by Guardian's Dan Sabbagh:

Victims have a veto. David Cameron, giving evidence, said that the test of the effectiveness of the Leveson Inquiry would be its impact on those who have suffered from press intrusion. "If families like the Dowlers feel this has really changed the way they would have been treated, we would have done our job properly," he said. (Sabbagh 2012, p. 11)

This portrayal of victims as "the stakeholders", the only demographic to benefit from press reforms, was more pronounced in the Guardian newspaper where several headlines contained a reference to the victims as can be seen in the headline, "Leveson report: PM defies press victims: $1.30 \mathrm{pm}$... Lawyer for Milly Dowler's parents says PM has 'failed the Dowler test'" (Wintour and Sabbagh 2012, p. 1). A similar headline from Guardian stated: "When Leveson reports, parliament must act swiftly.... We would be betraying the media's victims if we ignored its findings" (Miliband 2012, p. 26). This construction of victims as "the stakeholders" was also identified in the other newspapers' coverage of the media reform debate, although not with the same intensity, and it was used a bit differently-to critique arguments advanced by the victims' campaigners as can be seen in the headline "Hacked off don't speak for victims, insists $7 / 7$ father" (Cohen 2013, p. 28). This construction of victims as "the stakeholders" may have accounted for victim-related sources emerging among the top three sources used in the coverage as shown in Table 9.2.

From the statistics, we see that just three groups (press related, policymakers and press abuse victims) made up 79.8 per cent of the sources (see Tables 9.1 and 9.2). While I share the view that the press were vital participants because the debate was about them, policymakers were important because they were the decision-making sphere, and the victims were vital because they had first-hand experience relevant to the debate, I argue that limiting the debate in the media's public sphere to this narrow spectrum of stakeholders risks leaving out large sections of the society that do not fall within these major categories but are inarguably stakeholders in the debate on press standards. In a democracy, how the press should be regulated is a matter that concerns the whole of society and that ought to have been reflected in the distribution of sources. The risk to democracy here is 
that only a few sections of society dominated a debate on a matter that concerns all. One of the problems with this is that some sections of society may develop apathy towards the debate and not see it as a matter that concerns them. It can be argued that this narrow spectrum of sources reduced the diversity of views about press reform expressed in the media and limited the options that were available to policymakers from which they made decisions on how to regulate the press.

\section{CONCLUSION}

The coverage of the press reform debate featured a doubly narrow spectrum of sources, "doubly narrow" because the range of sources was narrow and within the narrow spectrum, access tilted heavily in favour of press-related sources. Policymakers came next to the press in the hierarchy of access to deliberations about media policy in the media's public sphere. One of the challenges with making effective media policies is that both the media and policymakers are self-interested parties. The power of political leaders to make policy decisions on the media and the power of the press to either make or mar a political career make them collaborate with one another for "favourable" press coverage to promote a political career in exchange for "favourable" media policies that advance the interest of the commercial press. I argued that the reciprocal relationship between policymakers and the press makes it hard for policymakers to advance effective media reforms.

This collaboration between the press and policymakers reflected in how some politicians advanced the arguments of the bulk of the press in their opinion articles. As long as the media possess the power to mar political careers, it would be difficult for the politicians to give complete backing to effective press reform. That is why this book argues that external pressure outside the press and the government is essential for the creation of the kind of media policy that will produce an accountable press. This will be discussed further in Chap. 10. This chapter also points out that in the coverage of the press reform debate, victims of press abuse were represented as "the stakeholders" rather than "a stakeholder" of the debate. I acknowledged the importance of the victims to the debate but argued that limiting the stakeholder status to those who have been hurt by the press results in a limited range of views and risks shutting down more neutral voices that could have enriched the debate in the media's public sphere. Having examined how sources were distributed in the press coverage of 
the media policy debate that followed the NoTW phone hacking scandal, the next chapter discusses the importance accorded to diverse issues of concern in the public sphere.

\section{REFERENCES}

38 Degrees. (2017). Stop Murdoch taking over Sky [Online].. Available at: https:// speakout.38degrees.org.uk/campaigns/murdoch-petition.. Accessed: 8 July 2017.

Allan, S. (2010). News culture: Issues in cultural and media studies (3rd ed.). Maidenhead: Open University Press.

Allan, S., \& Zelizer, B. (2010). Keywords in news and journalism studies. Maidenhead: Open University Press.

Allen, V., \& Evans, R. (2012, November 30). Cameron has let us down, say phone-hacking victims. Daily Mail.

Ashcroft, M. and Oakeshott, I. (2015). British Prime Minister and an obscene act with a dead pig's head [Online]. Daily Mail, 20 September 2015. Available at:https://www.dailymail.co.uk/news/article-3242550/Cameron-pigbemused-look-face-future-PM-took-outrageous-initiation-ceremony-joiningOxford-diningsociety.html. Accessed 22 Feb 2020.

BBC News. (2014). Maria Miller quits as culture secretary after expenses row. $B B C$ News, April 9 [Online]. Retrieved January 6, 2017, from http://www. bbc.co.uk/news/uk-politics-26951464.

BBC News. (2016). John Whittingdale row: Who is he and why does the story matter? BBC News, April 13 [Online]. Retrieved January 6, 2017, from http:// www.bbc.co.uk/news/uk-politics-36033415.

BBC News. (2017). What are the issues in Fox's Sky deal? BBC News, June 29 [Online]. Retrieved March 28, 2017, from http://www.bbc.co.uk/news/ business-40434381.

Beattie, J. (2013). Revenge of the politicians; day UK press was shackled PM Cameron bows to pressure \& paves way for a 'ministry of truth'. Daily Mirror, March 19, p. 26.

Chapman, J. (2013). Now the economist rejects rotten' plan to shackle free press. Daily Mail, March 22.

Cohen, T. (2013). Hacked off don't speak for victims, insists $7 / 7$ father. Daily Mail, March 28, p. 28.

Curran, J., \& Seaton, J. (2010). Power without responsibility: Press, broadcasting and the internet in Britain (7th ed.). London: Routledge.

Dean, S. (2017). Culture secretary Karen Bradley to make decision on Fox's Sky takeover next week. Daily Telegraph, 20 June [Online].. Available at: http:// www.telegraph.co.uk/business/2017/06/20/culture-secretary-karen-bradley-make-decision-foxs-sky-takeover/.. Accessed 7 July 2017. 
Department for Digital, Culture, Media and Sport. (2019). The Cairncross Review: A sustainable future for journalism, February 12 [Online]. Retrieved July 3, 2019, from https://assets.publishing.service.gov.uk/government/uploads/ system/uploads/attachment_data/file/779882/021919_DCMS_ Cairncross_Review_.pdf.

Embley, L. (2012). Do you want to be the man who destroys the essence of free speech, Mr Cameron? Daily Mirror, November 29, pp. 8-9.

Financial Times (2018). Comcast wins auction for Sky with $£ 30$.6bn bid [Online]. Financial Times. Available at: https://www.ft.com/content/a02224a2-be9611e8-8d55-54197280d3f7. Accessed 31 Aug 2019.

Fletcher, K. (2015). The journalist;s handbook. Hampshire: Pan Macmillan.

Fourie, P. J. (2001). Media studies: Institutions, theories and issues. Lansdowne: Juta and Company Ltd..

Fowler, N. (2013). Comment: My advice to Tory MPs: However painful, Conservatives should vote against their party on press regulation. Guardian, March 18, p. 24.

Franklin, B. (2002). Social policy, the media and misrepresentation. London: Routledge.

Glover, S. (2012). Leveson and how the luvvies (who made millions using the media) should beware what they wish for. Daily Mail, October 8 .

Graber, D., \& Dunaway, J. (2014). Mass media and American politics. Washington: CQ Press.

Greenslade, R. (2013a). The Spectator says NO to the new press regulator. Guardian, March 20.

Greenslade, R. (2013b). The Economist calls press regulation deal 'a shameful hash'. Guardian, March 22.

Guardian. (2016). From launch to takeover: Rupert Murdoch and Sky. 9 December [Online]. Available at: https://www.theguardian.com/business/2016/ $\mathrm{dec} / 09$ /fromlaunch-to-takeover-rupert-murdoch-and-sky. Accessed 15 Feb 2017.

Haas, T. (2012). The pursuit of public journalism: Theory, practice and criticism. London: Routledge.

Hallin, R., et al. (1993). Sourcing patterns of national security reporters. Journalism Quarterly, 70(4), 753-766.

Harcup, T., \& O'Neill, D. (2010). What is news? Galtung and Ruge revisited. Journalism Studies, 2(2), 261-280.

Hill, A. (2012). 7/7 survivor accuses PM of 'siding with the press barons' over Leveson report. Guardian 29 November.

Huhne, C. (2013). People despise politicians -But whose fault is that? Guardian, September 9 , p. 36.

Johnson, B. (2012a). Newspapers are worth fighting for - Even when they're wrong; our imperilled press has proved its value. Don't let over-regulation weaken it fatally. Daily Telegraph, October 29, p. 22. 
Johnson, B. (2012b). It's one of the glories of this country that we have free, exuberant media. They keep public life much cleaner \& that makes Britain a wonderful place to live. The Sun, November 29, pp. 10-11.

Keeble, R. (2008). Ethics for journalists. London: Routledge.

King, I. (2016). Sky agrees to takeover by 21 st Century Fox. Sky News 15 December 2016 [Online].. Available at: http://news.sky.com/story/sky-agrees-to-takeoverby-21st-century-fox-10696997.. Accessed: 15 Feb 2017.

Lester, A. (2012). Comment: My vision of a Leveson law: Use of the supreme court and judicial review can renew confidence in a system of self-regulation. Guardian, December 11, p. 30.

Leveson, B. (2012). An inquiry into the culture, practices and ethics of the press. 4 , pp. 1477-1985 [Online]. Retrieved December 27, 2016, from http://webarchive.nationalarchives.gov.uk/20140122145023/http://www.official-documents.gov.uk/document/hc1213/hc07/0780/0780_iv.asp.

Luckhurst, T. (2012). Our press must remain free. Daily Telegraph, October 25, p. 25.

Mason, R. (2012). State control of press still on the table, says media minister. Daily Telegraph, November 26, p. 8.

Mason, R. and Martinson, J. (2016). Theresa May had private meeting with Rupert Murdoch. Guardian 29 September [Online]. Available at:https:// www.theguardian.com/media/2016/sep/29/theresa-may-meeting-rupertmurdoch-times-sun. Accessed 3 Jan 2017.

McCombs, E., et al. (1997). Communication and democracy: Exploring the intellectual frontiersin agenda-setting theory. Lawrence Erlbaum Associates: Mahwah.

McCombs, M. E. (2004). Setting the agenda: The mass media and public opinion. Cambridge: Polity Press.

McCombs, M. E. (2014). Setting the agenda: The mass media and public opinion (2nd ed.). Cambridge: Polity press.

Media Reform Coalition. (2017). Murdoch's lobbying efforts are increasing; New analysis finds [Online]. Available at:https://inforrm.wordpress. com/2017/02/06/media-reform-coalition-murdochs-lobbying-efforts-areincreasing-new-analysis-finds/. Accessed 15 Feb 2017.

Miliband, E. (2012). When Leveson reports, parliament must act swiftly. Guardian, November 26, p. 26.

Negrine, R. (1989). Politics and the mass media (2nd ed.). London: Routledge.

Neild, B. (2013). Editors speak out on regulation. Guardian, March 12, p. 8.

News Corporation. (2017). Who we are. News Corporation [Online]. Available at:. https://newscorp.com/who-we-are/. Accessed 11 July 2017.

Newsworks. (2016). Market overview [Online]. Retrieved January 14, 2017, from http://www.newsworks.org.uk/Market-Overview.

O'Carroll, L. (2012). Leveson inquiry report into press regulation now expected in November. Guardian, September 5. 
O’Carroll, L., \& Halliday, J. (2013). Press regulation: Leveson distances himself from plan for royal charter: Idea was not suggested to inquiry, judge tells MPs Report 'didn't recommend statutory regulation'. Guardian, October 11, p. 17.

O'Heffernan, P. (1991). Mass media and American foreign policy: Insider perspectives on global journalism and the foreign policy process. London: Greenwood Publishing Group.

Pickard, V. (2015). America's battle for democracy: The triumph of corporate libertarianism and the future of media reform. Cambridge: Cambridge University Press.

Putnis, P. (2000). Newspapers as political instruments in media policy debate. Agenda: A Journal of Policy Analysis and Reform, 7(2), 99-112.

Rayner, G. (2012). Don't let newspaper victims set the rules, PM is warned. Daily Telegraph, November 29, p. 6.

Reuters. (2018). Fox, disney and now comcast - A timeline of Sky takeover proposals [Online]. Reuters. Available at:. https://www.reuters.com/article/ussky-m-atimeline/fox-disney-and-now-comcast-a-timeline-of-skytakeover-proposals-idUSKCN1GB2HG. Accessed 31 Aug 2019.

Ross, T. (2012). Politicians in control risks media like Russia's, warns Lebedev. Daily Telegraph, November 26, p. 8.

Rozell, M. J., \& Mayer, J. D. (2008). Media power, media politics (2nd ed.). Plymouth: Rowman \& Littlefield.

Sabbagh, D. (2012). Leveson inquiry: Lessons learned: 12 things the inquiry has taught us. Guardian, November 28, p. 11.

Sanders, K. (2008). Communicating politics in the twenty-first century. Hampshire: Palgrave Macmillan.

Shoemaker, P., \& Vos, T. (2009). Gatekeeping theory. London: Routledge.

Sweney, M. (2013). Hugh Grant: Press regulation talks are 'betrayal' of newspapers' victims. Guardian, October 9.

Sweney, M. (2016). Petition calls for Ofcom to investigate Rupert Murdoch's Sky bid. Guardian, 16 December [Online].. Available at: https://www.theguard$\mathrm{ian} . \mathrm{com} / \mathrm{media} / 2016 / \mathrm{dec} / 16 /$ petition-ofcom-rupert-murdoch-sky-bid-foxkaren-bradley.. Accessed 7 July 2017.

Toynbee, P. (2013). Will the press repent its nasty ways? Don't hold your breath. Guardian, March 19, p. 29.

Vos, T., \& Heinderyckx, F. (2015). Gatekeeping in Transition. London: Routledge. Wahl-Jorgensen, K., \& Hanitzsch, T. (2009). The handbook of journalism studies. London: Routledge.

Waterson, J. (2018). Leveson 2: Government to be taken to court over cancelled inquiry [Online]. Guardian, 21 May 2018.. Available at:https://www.theguardian.com/media/2018/may/21/leveson-2-government-taken-courtover-cancelled-inquiry.. Accessed 20 Aug 2018.

Winnett, R. (2012). End these cosy media links, politicians told; call for ban on hidden meetings between newspaper staff and leading members of political par- 
ties that lead to concern among public openness. Daily Telegraph, November 30, p. 11.

Wintour, P., \& Sabbagh, D. (2012). Leveson report: PM defies press victims. Guardian, November 30, p. 1.

Open Access This chapter is licensed under the terms of the Creative Commons Attribution 4.0 International License (http://creativecommons.org/licenses/ by $/ 4.0 /$ ), which permits use, sharing, adaptation, distribution and reproduction in any medium or format, as long as you give appropriate credit to the original author(s) and the source, provide a link to the Creative Commons licence and indicate if changes were made.

The images or other third party material in this chapter are included in the chapter's Creative Commons licence, unless indicated otherwise in a credit line to the material. If material is not included in the chapter's Creative Commons licence and your intended use is not permitted by statutory regulation or exceeds the permitted use, you will need to obtain permission directly from the copyright holder.

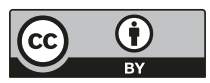

